\title{
Institutionalising 'Waqf' for Realising the Shared Development Objective by Islamic Banks and Financial Institutions
}

\author{
Muhammad Ayub * \\ The Editor, Journal of Islamic Business and Management
}

"Never will you attain the good (reward), unless you spend (for others' welfare) of that which you love; and whatever you spend indeed, Allah knows it well” [Al-Qur'ān, 3:92]

\section{Keywords}

Islamic Banks

Corporate Social

Responsibility (CSR)

Shared Prosperity

Waqf

Philanthropy

Micro Financing

\begin{abstract}
Islamic financial system has evolved since last four decades with the objective to do justice to all economic agents in an economy. But, the Islamic Banks and Financial Institutions (IBFIs) have been working on the conventional paradigm by replicating the interest based products. Justifying the contracts on the basis of legal form, without ensuring the underlying real spirit of the transactions [economic substance], amounts to abusing the Sharī'ah principles (Dusuki \& Abdullah, 2007, Hanif, 2016). Waqf is a civil societal institution and a crucial part of the 'virtuous sector' of Islamic economy. It involves voluntary charity of perpetual tendency for benefit of mainly the poor. This editorial explores the areas that might be helpful in revitalisation of the institution of waqf by involving banks and other financial institutions for sustainable socio economic development of society and the economy. Based on the available literature, it suggests that establishing and running $a w q \bar{a} f$ at macro and micro levels has to be a common feature of the Muslim society, while banks may facilitate in establishing and running such awqāf. This way, IBFIs could make visible contribution through innovation and entrepreneurship. The editorial may help the IBFIs and the regulators, as also the researchers, to restructure the banking and non-banking financial institutions for benefiting from the potential of waqf for welfare of the poor and vulnerable sections of the societies at broader levels.
\end{abstract}

KAUJIE Classification: E2, I23, L2

JEL Classification: L31, M14, E5

(C) 2018 JIBM. All rights reserved.

\section{INTRODUCTION}

The ethic-centric approach of the Qur'ān makes its teachings valuable and relevant for all who are concerned with the future of humanity. Sunnah of Prophet Muhammad (PBUH), a

${ }^{*}$ Corresponding Author: Muhammad Ayub

${ }^{\dagger}$ Email: muhammad.ayub@riphah.edu.pk 
practical exposition of the message of Qur'ān, provides an institutional structure, the proper working of which could provide the humanity the best framework for welfare at broader level. One such institution is waqf that is a part of benevolence with the potential to uplift those who might not get the due share in the national wealth due to [any] inabilities or malfunctioning of the system.

The economic and financial system in vogue has miserably failed in creating harmonious and peaceful human societies. The major part of population even in the 'advanced' economies is facing the problem of relative poverty. According to Credit Suisse Research Institute (2018), top $1 \%$ of adult population occupies $47 \%$ of global wealth, and the bottom half $(50 \%)$ of adults own less than $1 \%$ (US\$ 3 trillion). The global financial system based on interest and speculative contracts is the main tool of the economic system in vogue leading to the persistent problems for the mankind. The money and credit created by the banking system goes to the holders of existing assets and swells the cash balances of the banks and the businesses, rather than being spent to create real business and support commodities sectors in the economies (Skidelsky, 2018). It resulted in increased inequality, the rich saving more than the poor, and thus enhancing their cash earnings. Essential measures are thus needed to reverse the rising trend of inequality.

The multilateral institutions like the World Bank, International Monetary Fund (IMF) have failed to reduce the gap between the extreme poor and the rich Millennium Development Goals (MDGs) and the same is the trend with regard to the Sustainable Development Goals (SDGs) for 2030. The approach, models, schemes and the plans based on exploitative tools like interest, short selling and emphasis on 'self-interest' of the individuals and institutions without care for social responsibility might never be helpful in achieving balanced and equitable growth.

Christine Lagarde, the IMF's head, expressed serious concern on the total value of global debt, in both the public and private sectors, that rocketed by $60 \%$ in the decade since the financial crisis starting in 2008 to reach an all-time high of \$182tn (Phillip Inman, 2018 ${ }^{1}$ ). "The lessons of 2008 have not been fully learned: stop risky lending by banks, address fiscal policy and reduce inequality" says Skidelsky (2018) ${ }^{2}$.

According to Gordon Brown, former prime minister of Britain, the leaderless world was moving into a decade of vulnerability, after a decade of stagnation in the global economy. "We are in danger of sleepwalking into a future crisis," he said when asked to assess the risks of a repeat of $2008^{3}$. Action against financial malpractice had not been tough enough and solving the problems now would be even more difficult as "the cooperation that was seen in 2008 would not be possible in a post-2018 crisis both in terms of central banks and governments working together". Adding that the excessive lending could be the main cause, he contended that a breakdown of trust in the financial sector in the next crisis would be mirrored by breakdown in trust between governments.

Working with the paradigm as discussed above, banks and financial institutions that use

\footnotetext{
${ }^{1}$ The Guardian: https://bit.ly/2IAGVQM to Mainstream Economics, published by Allen Lane

${ }^{3}$ The Guardian: https://bit.ly/2x616lc
}

${ }^{2}$ Professor of political economy at Warwick University and the author of Money and Government: A Challenge 
the wealth and resources of the society for their own benefit only, need to change their approach, and work for the shared prosperity. Hence, the most crucial requirement is the transformation from risk-free to the risk based model of investments and finance, in order to match the credit expansion with the growth in real economy and invoke market discipline (Chapra, 2008). The steps like changing the interest rates to expand or restrict the credit and varying the reserve requirements added by stricter regulatory penalties cannot resolve issues on sustainable basis. When the system allows imbalances by default, the spread of contagion through the banking system may cause havocs at the global level as we witnessed in the last decade.

Islamic finance, having Divine guidelines, provides the basis for benefit of the economy, and, in turn, the society at broader level by ensuring proper linkage between finance and the real business and economy. Maqāssid al-Sharī'ah, as envisioned in Islamic law, pertain to social as also economic aspects of human life, for Muslims as also non-Muslims. Justice in distribution of income and resources, disclosure in exchange contracts, right of information and knowledge are relevant to all human beings. Accordingly, Islamic finance has to be integrated with Islamic economics to lift up the both sub-disciplines within the margins of Shar'̄'ah as indicated in Qur'ān and Sunnah.

The above, however, is possible only when IBFIs operate for implementing the unique features of Islamic finance, namely the risk sharing and adding value to broad-based socioeconomic growth of national and global economies. According to the Thomson Reuters' (2019) "State of the Global Islamic Economy Report 2018/19" the assets of Islamic finance, estimated at US\$2.4 trillion in 2017, are expected to surge to US\$3.8 trillion by 2023 (P.4Executive Summary). This, however, is not expected to realize the objectives as visualized in the theory of Islamic economics and finance. The Muslim investors are becoming increasingly distrustful of Sharī'ah compliant investment products: "They feel they are being given conventional products with Islamic labels" (Hussain, Shahmoradi, \& Turk, 2015).

The objective of this editorial is to briefly discuss the principles and the strengths of Islamic finance, failure of IBFI's in benefitting from the systemic strengths, and suggest the measures and institutions enabling banks to realize the desired objectives, with focus on the institution of 'waqf'. We plan to discuss the all-pervasive 'success' for Islamic banking institutions in accordance with maqāssid al-Shar'̄'ah by helping the poor and fulfilling CSR related functions by benefiting from waqf institution.

Islamic financial system is bound to adhere the principles and operational guidelines, as agreed upon by scholars including: i) Seeking rent on money capital is not allowed; ii) While taking business risk is a precondition for valid return, generating and exchanging speculative risk has to be avoided; iii) Risk must not be separated from real transactions owner has both risk and reward; iv) All contracts have to be enforced to ensure transfer of risk and reward to the parties as per terms of the relevant contracts; v) Short selling is strictly prohibited except under salam conditions; vi) The goods with their intrinsic values ( $a^{6} y \bar{a} n$ ) have to be given different treatment in sale and exchange, from money, monetary units and the fungible goods that could serve as money; and vii) emphasis on transparency and disclosure on all matters that may pertain to rights and obligations of any of the parties 
to exchange.

It implies that the real task of the regulators is to ensure that all funds provided by the banks are related to the real business and production activities. Therefore, all Islamic contracts for business, even those creating debt on the basis of fixed return modes like credit (mu'ajjal - murābahah) and forward (salam) sales could lead to growth and development, provided their Shari' 'ah essentials are implemented in letter and spirit.

The above principles lead to strengths of the Islamic system which, among others, include:

i) Prohibition of riba and permission of profit in exchanges lead to equitable and sustainable growth of economies without booms and bursts;

ii) permission of forward trading in the form of 'salam' provides opportunity to utilize the real potential of the economy without creating inflationary or deflationary impact, while keeping the money and credit creation in line with potential of the real economy in short and medium term;

iii) while debt creation by way of real sector businesses is allowed, mere financialisation - advancing money and credit without any link with the real economy is prohibited; and

iv) due weightage is given to all four aspects of economic objectives, social objectives, Sharī'ah compliance and the risk management, thus fulfilling the objectives of efficiency, profitability and social responsibilities.

World Bank and Islamic Development Bank Group (2016) describes the enabling features of Islamic finance system in the words, "The distinct attributes of Islamic banking that encourage sharing risk, prohibiting interest, enhancing financial stability, and promoting investment in morally acceptable projects are advantages that could make it better adapted to the local environment, not only in Islamic countries, but also in low-and middle-income non-Muslim countries" (p. 68).

\section{The IBFIs Need to Re-think}

The IBFIs have been increasingly compromising on the fundamental principles and strong ethical values for mere profit motives (Mohammad \& Shahwan, 2013). The continuing crises in global economy and finance must inspire the IBFIs to follow a different paradigm. They need to explore such modes and instruments that could play role in promoting the real economy. It is possible only when they avoid the products like tawarruq, al-'inah and financial derivatives including futures, options and swaps that are the tools of extraordinary benefits to innovators of complicated synthetic products, but harmful for masses and the global economy and finance. Forward sales and creating financial assets on the basis of future potential of growth in goods and services is valid only when it is subjected to the conditions imposed for the valid salam transactions. It refers to the need for controlling money and credit in national economies and global finance. Inflation targeting, monetary policy and its management have to be geared to ensure that financial flows are just sufficient to facilitate the growth of the real sector. It could be accomplished by the IDB or any other apex forum like the Standing Committee for Economic and Commercial Cooperation of the Organization of the Islamic Cooperation (COMCEC). 
Charitable giving is obligatory in some cases (zakāh and 'ushr) and desired as a whole, therefore common, in a Muslim society. It is more obligatory for the banks themselves, since they manage a huge chunk of the society's resources and are more able to assist the needy. IBFIs need to benefit from this trait of the Muslim societies. In addition to that, by sacrificing some of their own resources, they need to make social welfare an objective that has to be as important to them as earning profits.

Accordingly, the vision and mission statements of renowned Islamic banks like Meezan bank and Al-Baraka Bank, for example, indicate that Islamic banking is to be developed to facilitate the implementation of an equitable economic system, providing a strong foundation for establishing a fair and just society for mankind. This objective would be realised only if the rewards of Islamic banking growth are equitably distributed and reach the lowest strata of the society. Islamic banks must reach out to the less fortunate who are struggling for sustenance rather than centering on the wealthy, already blessed with ample resources.

It would also resolve the issue of negative perception about current Islamic banking practices. A recent study (Khan \& Ramzan, 2015) indicated the people believing that an Islamic bank should primarily aim at social welfare while pursuing commercial objectives for its sustainability. Thus, the performance of an Islamic bank cannot be hailed on its commercial success unless the achievements of its social objectives are at the same level. Qard al-hasan is a mode which encompasses these values. Islamic banking industry needs to consider a portion of demand deposits to be utilized for provision of qard al-hasan, and start a scheme for philanthropy by collecting qard al-hasan time deposits from wealthy individuals. Additionally, to increase access to finance by underserved segments, Financing products for small farmers, small projects and businesses based on qard would be a solid step toward improving the prevailing perception.

While doing this vital service to the community, the awqāf would have to adopt safeguards against potential problems of recovery. Community guarantees, as well as social pressure by the members of groups of financing recipients, could produce the best results in this regard. They also need to create awareness among the public in general and the qard al-hasan recipients in particular about the importance of timely repayment of loans as per Sharī'ah instructions.

There are no Sharī'ah issues if the mudārib (bank) and rab al-māl (depositors) agree that a part of their profit will go to charity. Depositors' consent and the regulatory approval would be required, and there would have to be adequate disclosure, transparency and the free consent of the depositors. Hence, a part of the total net profit on deposit pools, prior to distribution between the pools (depositors) and the bank as mudārib, could be contributed to the qard al-hasan fund. If any waqfs are established by the banks, the depositors may be encouraged to contribute a part of their deposits or profits to such waqf pools for providing qard al-hasan to smallholders.

\section{Developing Value based Investing and Banking}

The principles and the strengths as discussed above tend to imply that IBFIs would be operating to create real value in the economy along with just treatment with all the stakeholders. 
In recent years some development has been witnessed in that direction. According to the IFN Asia Report 2018, there has been increasing emergence of the concepts and initiatives supporting ethical, responsible or moral ways of financing the projects. The concepts of socially responsible investments and value-based intermediation are being explored. The whole idea of Value-Based Investments (VBI) is maximizing benefit for the masses and minimizing harm, and this has to be the agenda of the Islamic banking and finance institutions.

But, the concept of VBI and ethical investments has to be clarified to exclude all interest, short-selling and speculation based investments that, instead of creating fresh additional wealth and resources for the mankind, merely lead to exploitation of the masses by a few. Currently, as the regulators and the policy makers at the states' level are not taking such bold steps, the financial institutions are operating almost on the same line and length to maximize their earnings without taking care of the business and moral ethics.

All institutions in Islamic perspective have to work in the welfare-based framework to provide education, health and other civic amenities for the public in general and the poor, small farmers, small traders, home-based businesses and Small and Medium-Sized Enterprises (SMEs), in particular. The virtue of benevolence, in addition to other virtues like justice and truthfulness, has been identified by Islam as the prime value that strengthens the social bonds in a society. [Al- Qur'ān 2: 177; 2: 195; 2:261]

The opportunity for Islamic finance to develop instruments and funding solutions that support the global demand for green projects is vast and consistent with the significant commonalities it shares with the Socially Responsible Investments (SRI) objectives. As the world is becoming more eco-conscious, the demand for sustainable, responsible and green financial products has been growing. SRI are getting increased attention, as depicted by volume of assets-close to US\$23 trillion, by 2016 (GSIR, 2016). "Ten to 15 years ago, people were focusing on financial returns. Now, people want to understand the impact their money is making. People are asking where their money is going and what the impact of their investment is," shares Stuart Hutton, the chief investment officer at Simply Ethical.

\section{Waqf and its Role in Welfare}

Technically, waqf refers to tying-up by someone a property in perpetuity for any virtuous purpose or for benefit of any specified group of persons. In other words, waqf involves retention of a property by someone for the benefit of a charitable or humanitarian objective, or for a specified group of people. The ultimate purpose of the waqf has to be virtue and piety by way of helping those who are in problem (Çizakça, 1998). Waqf that has to be irrevocable, perpetual, and inalienable, played crucial role for socio economic development, particularly in Ottoman empire covering Turkey, Middle East and Eastern Europe (Çizakça, 1998).

The potential of waqf has remained untapped over the last 200 years due to overwhelming status of modern corporations and involvement of interest, short selling and speculation. To revive the institution, a number of authors have presented the idea of waqf based microfinance for poverty alleviation (SESRIC, 2015). Development of the Islamic finance over 
last few decades has opened up many possibilities in terms of new structures for financing based on waqf assets.

\section{Waqf Law and related Framework ${ }^{4}$}

A comprehensive legal structure is required for establishing waqfs at micro and macro levels covering all socio-economics areas, particularly those pertaining to banking and nonbanking financial institutions. The waqf law may provide a comprehensive definition of both permanent and temporary waqfs. The framework must explicitly cover various types of waqf: family and social waqf, direct and investment waqf, cash waqf, qard al-hasan waqf and corporate waqf.

It needs to be provided in the case of casf waqf that the trustee would ensure perpetuity by investing the waqf fund carefully in any Shari' ${ }^{-}$ah permissible projects, stocks or the mutual funds. The revenue so generated could be distributed in different proportions for qard alhasan, charitable avenues and management expenses, or added to the capital as Self-Finance Device (SFD) (Fikry, Serilkhetim, \& Muneeza, 2018).

The legal framework should encourage creation of new waqf by minimizing financial and non-financial costs of waqf creation and management. Given the many benefits of cash and corporate waqfs, law must explicitly provide a framework for them, including their investment dimension. The framework may provide for issuance of waqf $s u k \bar{u} k$ and establishment of waqf based Islamic Micro finance institutions that may mostly provide qard al-hasan; but in some cases, may also finance by way of partnership, sales and ijärah.

Cash waqf and waqf sukük or certificates could be used to mobilize capital for waqfs. Besides charity of perpetual nature and casual donations by the public, other sources of fund for $a w q \bar{a} f$ related activities and projects could be the government institutions dealing with poverty alleviation (Ahmed, 2007).

The law has to ensure that representatives of the creators of awq $\bar{a} f$ may not involve in misappropriation. The role of regulators is important in appointment and monitoring. They have to decide the eligibility criteria for a mutawalli or nāzir or trustee manager not only covering aspects of integrity and trust-worthiness but also professional competence.

An Islamic Micro Finance Network (IMFN) came into existence in Pakistan in 2009 to promote Islamic microfinance sector. The IMFN is playing role for promoting Islamic microfinance industry by product development, institutional capacity building, donor linkages and up-scaling the Islamic Microfinance Institutions. But, the IMFN is not using the waqf institution for funding the micro finance activities. However, Akhuwat foundation (Pakistan) has achieved significant milestones in the area of microfinancing.

\section{IBFIs and Role of Waqf for Empowerment of the Poor}

For effective socio-economic inclusion in any developing country, it is necessary that financing to the extreme poor and to small farmers, businesses and entrepreneurs be based on qard al-hasan or carry relatively lesser charge. Any scheme that involves an unbearable

\footnotetext{
${ }^{4}$ We take here Pakistan as a case study; similar may be the situation in almost all Islamic countries requiring changes in the legal framework for proper functioning of waqf system.
} 
charge to groups having small means would result in negative effects such as higher income inequality and soaring interest (Adams \& Von Pischke, 1992). Credit costs combined with the increasing cost of other inputs work as a double-edged sword against small farmers, micro-level commodity producing units and SMEs. These lenses may be considered different from conventional financial wisdom of risk-return, however, very much in line with Islamic financial system aspiring for equitable distribution of wealth.

Hence, Islamic banks need to finance the target groups by means of qard al-hasan in order to reduce poverty and develop the economy on sustainable basis. They need to allocate a part of the equity and the deposit base to finance demographic segments that cannot get the required funds in the competitive financial markets due to higher costs or collateral requirements. They can also accomplish this job by creating and managing cash waqf (Çizakça, 2000) and perpetual or time-bound al-Khair Șukük for socio-economic development. Philanthropists would make a perpetual donation of the cash capital to provide financial support to small landholders for increasing production capacity. To restructure their operations on the suggested model they need to create subsidiaries for financing the agriculture, micro businesses and the SMEs (Ayub, 2002).

Enabling small entrepreneurs and farmers to produce goods and services at affordable costs may benefit the society and the economy through a number of linkages. Muslims are required to help one another in all matters of common concern (Qur'ān 5:2), and banks and other institutions need to facilitate them in this noble cause. They also need to distinguish between the two categories of the indigent needing funds to meet their consumption needs. Some may be eligible to receive $z a k a \bar{h}$ funds/charity, and some may just need bridge loans for their social or production needs repayable at the harvest or time of cash flow.

Akhuwat, presently working in Pakistan mainly on the basis of qard al-hasan, is in a position to serve as a role model for banks in this regard. Promotion of Islamic banking in its true sense, with an emphasis on banks' role in financing small farmers and SMEs, is one step towards this end. The default ratio of such financing is lower than for general financing by the commercial banks. Akhuwat has used the strategy of group lending in a customized way by capitalizing on the social capital of family (For relevant data and figures on Akhuwat, see Harper, 2011; Iqbal \& Shafiq, 2015; Khan, Siddique, \& Muhammad, 2018).

The ISRA/ Riphah study (IRP 97/2017) on Pakistan has referred to the view of some experts suggesting that the SBP needs to mandate every bank to create separate micro and SME qard al-hasan based financing structures. Further, Islamic banks need to re-orient their strategies to finance small landholders in particular and the commodities sector in general, rather than focusing on financing the government budget deficit or big corporates.

\section{Islamic Banks Issuing Perpetual or Time-bound Charitable Șukukk}

The banks would have to take the lead in creating waqf and issuing Al-Khair Șukük for sustainability of the scheme. Perpetual "Al-Khair Șukük" could be issued to those who wish to become a part of the social welfare scheme on perpetual basis, and the proceeds would be used to provide qard al-hasan to small farmers and SMEs. The banks would be able to issue these $s u k \bar{u} k$ through a Special Purpose Vehicle (SPV) created for this purpose. Since 
the very purpose of issuing such șukük is to attract philanthropists to take part in welfare and charitable pursuits, these șukuk would not bear any profit or return on investments for the holders. However, these $s u k \bar{u} k$ may be registered with stock exchanges for trading. Thus, if any of the affluent persons wish to give their excess funds for ever or for any given time, [till they may need for their family expenses] $s u k \bar{u} k$ could be issued to them, and if holders of time bound $s u k \bar{u} k$ wish to withdraw from the scheme, they could do so by exchanging the $s u k \bar{u} k$ in the securities market at par to others, intending to participate in the social welfare scheme. (Khan, 2016; Khan \& Sakinah, 2017). Takäful reserves and profit equalizing reserves can be introduced as a safeguard for the beneficiaries in case of loan defaults caused by any unforeseen events.

Introducing waqf șukuk would imply creating Islamic endowment for issuance of financial certificates that will represent donations of the individuals and corporate entities. Charitable $s u k \bar{u} k$ could be issued by Islamic banks to provide a sustainable source of funds for continuing qard al-hasan projects by them. Khan (2016) has suggested philanthropic $s u k \bar{u} k$ to provide people of small means with opportunities to have acts of perpetual charity to their credit. After a waqf fund is established by any bank, it may be issuing perpetual and redeemable charitable $s u k \bar{u} k$ so that it could serve as a hub for social inclusion in an area/society (Khan \& Sakinah, 2017).

The waqfs once created by the IBFIs could be replenished by: i) Shareholders allocating a certain percentage of the Islamic bank's profits for this purpose; ii) Account holders contributing, at their discretion, by direct donation or by a percentage of profits earned from their deposit/ investment accounts on a regular basis; and iii) The government and international donor agencies may donate to the waqf as part of their poverty alleviation initiatives.

One source for such waqfs could be the charity accounts maintained by IBIs in Pakistan to which penalty amounts on account of late payments are credited. Meezan Bank Limited has already established 'Ihsān Trust' for charitable and social service-related activities. As such, the banks' waqfs would also provide grants to the needy in addition to qard al-hasan for business and production purposes.

Another example is that of Al-Meezan Investment Management Company, which has launched a unique fund in collaboration with Karachi-based Indus Hospital. The money contributed to the fund is utilised in two ways. First, a person invests his excess funds in this scheme, with the arising profit going to Indus Hospital while the principal amount remains in the ownership of that person. Alternatively, a person invests the principal amount in Indus Hospital as a waqf. This amount will be used at the discretion of the Hospital's waqf committee. This is how support is provided to the hospital. Another example is the management of the Akhuwat qard al-hasan scheme through a joint venture with Ihsān Trust.

The functions of such waqfs may include: a) Provision of qard al-hasan (without any charge) for education and professional trainings.

b) Spending on provision of religious education, research in Islamic history, law and culture; and helping the community in performing religious rituals-salat and hajj.

c) Islamic microfinance for the poor farmers in rural areas and SMEs in urban areas 
(Hypothetical operations of such a waqf given in the Apendix).

d) Help in disaster management for running expenses and rehabilitation.

e) Financing for entrepreneurship in SME sector and project management in commodities and services sectors.

f) Awareness of Islamic business, finance, ethics, donations by way of waqf, zakāh and 'ushr.

The banks, particularly the Islamic financial institutions, may be obliged to create separate pools of funds within their core banking operations by giving separate legal entity status to such funds in the form of waqfs. They are under an obligation to address various strata of the society by introducing products that lead to a fair distribution of resources and wealth. Lessons could be learnt from the well-known social welfare institution Akhuwat, a sustainable qard al-hasan program in many cities in Pakistan (Khan \& Sakinah, 2017). The waqfs may issue charitable perpetual and/or time-bound $s u k \bar{u} k$ (al-Khair șukük) exchangeable on the secondary market for arranging funds on sustainable basis. The micro level Waqf Funds may finance projects or funding based on qard al-hasan, mudärabah or murābahah, keeping in view financial position of the recipients.

The banks may also persuade the rich to establish such waqfs or to contribute for them using the incentive of tax exemptions for social services available under Tax Ordinance 2001 and Income Tax Rules 2002. Such waqfs may be allowed to make a profit, but all profits would be applied to furthering the charitable purpose of the organisation. The banks' shareholders, management and trustees controlling the waqfs may not be allowed to use the waqf resources or profits for their salaries, perks, or any other personal gain.

The legal framework for macro and micro level waqfs and the matching institutions/process have to be provided for launching the desired system. For that purpose, the State institutions are required to provide a special legal framework for waqs for establishing all kind of waqf based entities and promoting $A w q \bar{a} f$ for socio-economic development.

\section{CONCLUSION}

There has to be some shift from the maximisation of shareholders' value to that of the "aggregate welfare of the stakeholders" (Grais \& Pellegrini, 2006). The IBFIs are expected to provide finance to the so-far unbanked groups from their equity or from philanthropists, considering it their CSR-related responsibility. As CSR continues to gain importance at global level, Islamic banks have the potential to fulfil it through waqf based qard al-hasan, and low cost financing through Islamic modes of financing.

Waqf based qard al-hasan model could be helpful in socio-economic development at grass-roots level if the Islamic banks and NBFIs initiate social welfare schemes based on charity leading to waqf funds. Necessary rules could be issued for the establishment of waqf by banks and allocations to them from equity as well as other sources including charities. Once any such scheme establishes its credibility as a social welfare entity taking care of the jobless and the poor, huge amounts of funds would be forthcoming to enable the banks to operate the scheme successfully. 
Islamic banks should donate money for formation of waqfs, which could then be augmented by donations and utilised to assist the jobless and the needy among the lower groups of the society. The central bank and the capital market regulators would be required to play a role by providing a framework that would make such schemes workable. It would be particularly needed for the issuance of Al-Khair Sukük and their exchange in the market in case a person wants to redeem the amount in case of time-bound $s u k \bar{u} k$. Further, the relevant authorities need to initiate 'Islamic banking community engagement programs' to engage with communities for promoting effective intermediation between the finance and the business and production sectors. It could be useful for resolving the problems faced by SMEs, micro businesses and small farmers in agriculture and its sub-sectors.

According to a study conducted in 2015 by Pakistan Peace Collective (PPC), Pakistanis give an estimated Rs. 650 billion in charity every year to mosques, seminaries, poor and homeless people, needy relatives, victims of terrorism and hospitals. According to the study, 78 percent of Pakistanis give charity, and 69 percent of charity is given in the form of money. If some of this compulsory ( $z a k \bar{a} h$ ) and voluntary charity (inf $\bar{a} q$ ) were channeled to provide employment to those who have some capacity to do business, it could bring about a social revolution in the society and contribute to sustainable development. The need of the hour is for Islamic banks to prove their credibility as institutions that promote socio-economic justice while doing business for profit.

Through the culture of voluntary giving in the form of waqf, it could be one of the best instruments for reducing socio-economic disparities and wealth redistribution between the rich and the poor. The institutions like waqf, zakāh, mutual takāful, and qard al-hasan based micro finance for agriculture, small businesses and SMEs have the potential to provide a strong basis for developing a comprehensive system ensuring social justice, equity and peace by enabling to fulfil the basic needs of society (Siddiqi, 2004; Zarqa, 1988).

Use of Fintech and getting online humanitarian and charitable contributions for the cash awqāf could also be effective in bringing broader level participation, especially for disaster management and rehabilitation after emergencies. Further, the possible positive externalities may also be highlighted while seeking contributions. For example, it may be highlighted how much difference a contribution of Rs.100,000 will make in funding one year schooling of a certain number of children and what impact it could make in life of the related families (Shaikh, Ismail, \& Mohd Shafiai, 2017).

It can be safely assumed that the regulators would allow the qard al-hasan that is provided through a waqf/philanthropic arrangement. They may also allow qard from a bank's own equity and to some extent from the deposits of such clients who are eager to seek the blessings of Allah by donating. The role of the SEC and the relevant State departments is crucial in providing a legal framework for institutions like waqf and for issuance of $s u k \bar{u} k$, subsidies and taxation. Central bank could play a role by persuading Islamic banks to engage in CSR and by setting mandatory targets for financing the priority sectors of small businesses and agriculture, particularly small landholders on qard al-hasan basis.

The government needs to incorporate poverty alleviation funds through qard al-hasan into public policy. The apex institutions of the State could thus encourage and/or oblige 
banks working in the private sector to be involved in qard al-hasan based schemes for the low-income, but crucial sectors of the economy.

\section{REFERENCES}

Adams, D. W., \& Von Pischke, J. D. (1992). Microenterprise credit programs: Deja vu. World Development, 20(10), 1463-1470.

doi: https://doi.org/10.1016/0305-750x(92)90066-5

Ahmed, H. (2007). Waqf-based micro-finance: Realizing the social role of Islamic finance.

Paper presented at the Integrating Awqāf in the Islamic Financial Sector, Singapore, 6-7 March.

Ayub, M. (2002). Islamic banking and finance: Theory and practice. Karachi, Pakistan: The State Bank of Pakistan.

Chapra, M. U. (2008). Innovation and authenticity in Islamic finance. Paper presented at the Eighth Harvard University Forum on Islamic Finance on Innovation and Authenticity, Harvard Law School, Cambridge, MA, 19-20 April.

Çizakça, M. (1998). Awqā $f$ in history and its implications for modern Islamic economies. Islamic Economic Studies, 6(1), 43-70.

Çizakça, M. (2000). A history of philanthropic foundations: The Islamic world from the seventh century to the present (pp. 2-10). Istanbul, Turkey: Boaziçi University Press.

Credit Suisse Research Institute. (2018). Global wealth report 2018. Retrieved from https://bit.ly/2zSln0Y

Dusuki, W. A., \& Abdullah, I. N. (2007). Why do Malaysian customers patronise Islamic banks? International Journal of Bank Marketing, 25(3), 142-160.

doi: https://doi.org/10.1108/02652320710739850

Fikry, M. A., Serilkhetim, M. H., \& Muneeza, A. (2018). An introduction to cash waqf. Halal Investing Journal. Retrieved from https://bit.ly/2DVAbLG

Grais, W., \& Pellegrini, M. (2006). Corporate governance and Sharī'ah compliance in institutions offering Islamic financial services (Policy research working paper no. 4054). World Bank, Washington, DC, WA.

GSIR. (2016). Global sustainable investment review. Retrieved from https://bit.ly/2o5bB1O Hanif, M. (2016). Economic substance or legal form: An evaluation of Islamic finance practice. International Journal of Islamic and Middle Eastern Finance and Management, 9(2), 277-295. doi: https://doi.org/10.2139/ssrn.2190053

Harper, M. (2011). Akhuwat: A case study. Retrieved from https://www.akhuwat.org.pk/

Hussain, M., Shahmoradi, A., \& Turk, R. (2015). An overview of Islamic finance (WP/15/120). International Monetary Fund, Washington, DC, WA.

Iqbal, Z., \& Shafiq, B. (2015). Islamic finance and the role of qard al-hassan (Benevolent Loans) in enhancing inclusion: A case study of akhwat. ACRN Oxford Journal of Finance and Risk Perspectives, 4(4), 23-40.

Khan, K., \& Sakinah, N. (2017). Promotion of agricultural and small business financing through qard hasan in Pakistan (No. 97/2017). Retrieved from https://bit.ly/2BN5Zlv 
Khan, M. F. (2016). Islamic institution for inclusive development. Retrieved from https://goo.gl/yEL9ec

Khan, M. M., \& Ramzan, M. (2015). Perceptions of stakeholders on Islamic banking in Pakistan. Journal of Islamic Business and Management, 219(3327), 1-18. doi: https://doi.org/10.12816/0026419

Khan, Z., Siddique, M., \& Muhammad, M. (2018). Minimizing operating cost of Islamic microfinance institutions: A case of akhuwat. Journal of Islamic Business and Management, 8(S), 320-329. doi: https://doi.org/10.26501/jibm/2018.080S-012

Mohammad, M. O., \& Shahwan, S. (2013). The objective of Islamic economic and Islamic banking in light of Maqāșid Al-Shar̄̄'ah: A critical review. Middle-East Journal of Scientific Research, 13(13), 75-84.

SESRIC. (2015). Integration of waqf and Islamic microfinance for poverty alleviation: Case studies of Malaysia, Indonesia and Bangladesh; Ankara-Turkey. Retrieved from https://bit.ly/2DZFt8I

Shaikh, S. A., Ismail, A. G., \& Mohd Shafiai, M. H. (2017). Application of waqf for social and development finance. ISRA International Journal of Islamic Finance, 9(1), 5-14. doi: https://doi.org/10.1108/ijif-07-2017-002

Siddiqi, M. N. (2004). Riba, bank interest and the rational of its prohibition (Visiting scholars' research series no.2). Islamic Development Bank, Jeddah, Saudi Arabia

Skidelsky, R. (2018). How economics survived the economic crisis. Retrieved from https://bit.ly/2V6JYFp

Thomson Reuters. (2019). An inclusive ethical economy state of the global Islamic economy report 2018/19. Retrieved from https://bit.ly/2BNbQqZ

World Bank and Islamic Development Bank Group. (2016). Global report on Islamic finance: Islamic finance - A catalyst for shared prosperity. Washington, DC, WA: World Bank.

Zarqa, M. A. (1988). Islamic distributive schemes. In Distributive justice and need fulfillment in an Islamic economy. leicester, UK: The Islamic Foundation. 


\section{Appendix}

\section{Description and Sketch of Micro Finance Waqf Fund}

Such waqfs may be allowed to make a profit in some cases, but all profits would be applied to furthering the charitable purpose of the organisation. For farmers with expected cash flow in near future, the Waqfs Fund may purchase a cow in milk for Rs. 100,000 (for example) and sell for Rs. 102, 000/ repayable after one year (murābahah basis). The waqf Fund may purchase a female calf for Rs. 50,000 and give it to a farmer for breeding on mudāarabah basis with PSR 1:3 (25\% for WF and 75\% for the client; farmer will be bearing all fodder cost), who may sell it when it is near to giving birth for Rs. 150,000. Out of the profit of Rs. 100,000 the WF will get $25 \mathrm{~K}$ while $75 \mathrm{~K}$ will go to the farmer. In case the farmer is very poor, he may be provided a calf of Rs 50,000 on qard al-hasan basis which when sold for about Rs 100,000 at the time of 'eid al-adha\% for example, he would repay the original debt of Rs. $50 \mathrm{~K}$. A simple sketch of this model by "ABC Islamic Bank" is given below:

\section{ABC BANK WAQF FOR SOCIA INCLUSION}

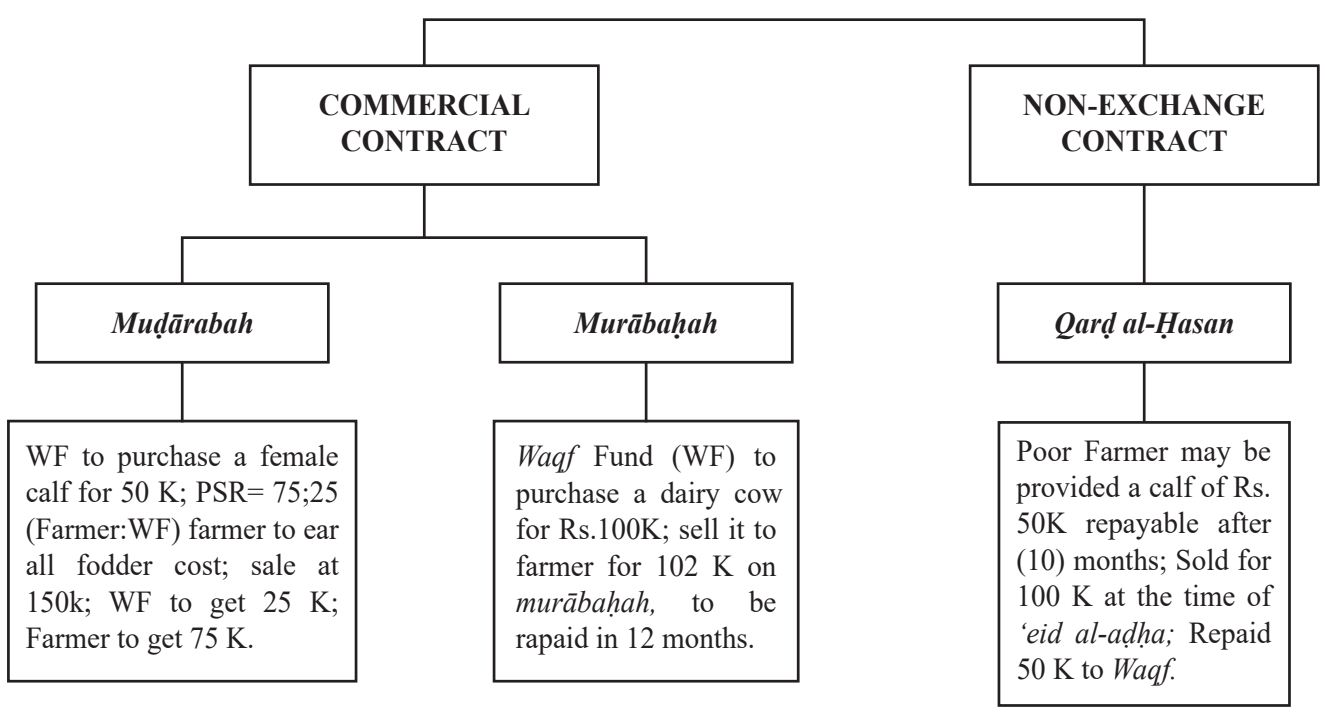

